\title{
Changes in Imports and Exports During the COVID-19 Pandemic in China
}

\author{
Yiming $\mathrm{Fu}^{1, *}$ \\ ${ }^{1} X i$ 'an Tieyi High School International, Course Curriculum, Xi'an, 71000, China \\ *Corresponding author.Email: c309@wanfeng.edu.bi
}

\begin{abstract}
At a time when the whole world is affected by the COVID-19 pandemic, the change in the global economic situation has become a more important issue for the whole country and its people. Trade between countries may also be different. Changes in imports and exports, and the subsequent rise and fall of the exchange rate. In addition, whether the epidemic will affect the initiative or ability of consumers and whether the production efficiency and productivity of producers can be well guaranteed. This article will also analyze the impact on China in this aspect from many perspectives. The research will pay attention to the changes in import and export in different regions in different periods and compare previous periods of similar epidemics. Therefore, it can be concluded that when the epidemic is serious, it will greatly impact the previous trade between different countries. It is also important to find a way to balance mutual interests.
\end{abstract}

Keywords: COVID-19 pandemic, change in imports and exports, production efficiency, China, different regions, balance mutual interests

\section{INTRODUCTION}

The Covid-19 pandemic dramatically influences people's lives and a country's whole economic system, especially for exchange markets. Sometimes it is difficult for traders to import or export goods and services to other countries' merchants. This paper will focus on how the Covid-19 pandemic influences China's exchange market. It is important to know that the definition of import and exports-international trade of a country with other countries is referred to as import and export. The word import refers to international trade where a country buys goods and services from another country. Still, the word export refers to international trade where a country sells goods and services to other countries. In addition, the government also put a tax on these goods imported to other countries and set a different price according to the one country's exchange rate. In China, in 2021 April 1, the government lowered China's VAT (value-added tax) on the import goods to 9 per cent, or 13 per cent, from 10 or 16 per cent [1]. Thursday, in 2012, supposed that the factors which affect China's exports and imports are that worker's productivity, exchange rate, inflation and interest rate, and real gross domestic product [2-4].
However, this paper only focuses on the influence of macroeconomic and sometimes ignores the change of citizens' purchasing behaviors. The Covid-19's influence on exports shows in the below figure exhibits that China's exports were relatively constant (except the first month in 2019) before 2020 when Covid-19 was spreading. And the predicted outcome and price was going to increase dramatically in 2020. [9]But after the pandemic in 2020's first month, the total price of China's exports decreased extremely. Because only China suffered a Covid-19 pandemic at the time, the rest of the world's export price increased. For example, at that time, masks and cleaning items are significant for people to ensure their body health. Some people would monopolize those goods, which make other needed imports and increase production.

Because it dramatically affects China's imports and exports, people need to analyze how to balance production and consumer purchasing behavior to make the exchange rate stable and not let production and price change too frequently. 


\section{MAIN BODY}

\subsection{Exports and Imports}

A pandemic could affect various kinds of facets, like the production of medicine, industrial products, wooden goods, jewelry, clothes, and foods [2]. Reporter Shao $\mathrm{Yu}$ in 2020 April said that the outbreak's influence on China's export was embodied in three aspects [4]. The first is a direct hit from falling foreign demand, the second is foreign economic stagnation leads to Chinese exports of raw materials and components in short supply, the third is a result of national border controls and restrictions on population trade logistics, among them, the falling foreign demand is likely to be the main shock. Exports are expected to have fallen by more than 25. 5 per cent in April and May.

Depending on the past pandemic and financial problems of 2008, many researchers analyzed that there are 'triple effects': disruption of domestic supply, reduction in global demand, and contagion effects spread through disrupted global value chains [5].

Table 1. Total aggregate shock pattern affected dramatically [5]

\begin{tabular}{lllll}
\hline $\begin{array}{l}\text { Timing of } \\
\text { impact }\end{array}$ & $\begin{array}{l}\text { Predicted } \\
\text { change in } \\
\text { Exports(\%) }\end{array}$ & $\begin{array}{l}\text { Supply } \\
\text { Shock }\end{array}$ & $\begin{array}{l}\text { Demand } \\
\text { Shock }\end{array}$ & $\begin{array}{l}\text { GVC } \\
\text { Contagion }\end{array}$ \\
\hline $\begin{array}{l}\text { Immediate } \\
\text { only }\end{array}$ & -38.7 & 13.0 & 49.8 & 37.2 \\
$\begin{array}{l}\text { First Lag } \\
\text { only }\end{array}$ & -23.7 & 29.0 & 3.4 & 67.6 \\
$\begin{array}{l}\text { Second } \\
\text { Lag only }\end{array}$ & 9.6 & 27.3 & 106.3 & -33.5 \\
$\begin{array}{l}\text { Third Lag } \\
\text { only }\end{array}$ & 6.8 & 59.7 & 36.6 & 3.8 \\
$\begin{array}{l}\text { Aggregate } \\
\text { Net Import }\end{array}$ & -46.0 & 11.4 & 16.0 & 72.4 \\
\hline
\end{tabular}

Compared to the period when SARS was widespread, the below graph shows normal exports' total revenue in China from 2015 to 2019. The right below expresses the strike for industrial production when the SARS pandemic widely spread. The price change of primary goods remained constant, but the industrial product price would increase continually [3].

\subsection{Comparing Different Economic Conditions}

Exports and imports for areas where they have more effect [3]. Since the Covid virus infects relatively more people in Hubei, Hunan, Guangdong, Zhejiang, and Henan, it would have a bigger effect on these areas' exports and imports. As of December 2019, exports from these regions accounted for 43 . 4 per cent of the national total, with Hubei, the worst-hit province, accounting for only 1.8 per cent. 4 per cent, while Guangdong and Zhejiang accounted for 38. 4 per cent which reduces the revenue of the whole area and income of people [3].

Because the exchange rate fluctuation also influences export, these two graphs compare the change of balance of trade and the yuan's exchange rate [3].

China's financial in 2020 suggested The reasons for the impact of import and export RMB exchange rate during COVID-19 are based on an economic basis, interest rate differentials and trade exports $[5,6]$.

First, economic fundamentals. The impact of COVID-19 on the economies of China, the United States and Europe is time-misplaced. The impact on the domestic economy is mainly concentrated in the first quarter. In contrast, the impact on the economies of Europe and the United States may be mainly concentrated in the second quarter. To be specific: On the Chinese side, the epidemic prevention and control situation continues to improve, the resumption of work and production is accelerating, and the early recovery of China's economy will support the RMB exchange rate with the twin forces of fiscal and monetary policies. As of May 19, the number of confirmed cases in the United States has exceeded 1. 5 million [7]. U.S. Economic growth fell $4.8 \%$ in the first quarter from the previous quarter, and the outlook for consumption, the biggest contributor to the economy, is grim. Consumption growth and consumer confidence have fallen sharply, and unemployment has risen to a nearly two-year high. In Europe, the epidemic's peak occurred in early April, and the number of newly confirmed cases declined. Still, the impact of the epidemic on the economy has begun to show. In the first quarter, the economic growth rate in the euro zone $(1.1739,-0.0016,-0.14 \%)$ declined by 3 . $3 \%$ year on year. In April, the MANUFACTURING PMI, the service PMI and investor confidence all declined sharply. The economic outlook is bleak [7].

The second is the spread factor. Negative impact on the economy in response to the outbreak, using various policy tools for China, the United States are rescuing financial institutions, enterprises and residents. Still, the unlimited zero interest rates plus quantitative easing are more radical, rapidly expanding in China. The United States national debt spreads, and then a sharp rise in the renminbi assets attractive to foreign investors. As China's financial market continues to open to the outside world and the introduction of relevant convenience measures, the inflow of foreign capital under the capital account is expected to remain stable, providing support for the RMB exchange rate. 
With trade exports in the first quarter of this year, the spread of the epidemic had a phased impact on China's imports and exports, with exports falling by $13 \%$ and imports by $3 \%$. The decline in exports was greater than that of imports, resulting in a narrower trade surplus. China's exports are expected to face multiple difficulties in the second quarter as the epidemic spreads worldwide. On the one hand, the epidemic in developed economies such as Europe and the United States has not yet been fully controlled. Weak external demand and logistics bottlenecks have reduced orders for export enterprises, making it difficult to maintain export growth. On the other hand, the Us government is likely to put pressure on China again on trade issues to deflect the economic and public pressure caused by poor control of the epidemic. The adverse factors above evolution or will promote the RMB exchange rate twoway concussion.

\subsection{Specific Period}

From the point of view of enterprises' labour return, the epidemic's impact emerged after the Spring Festival, seriously affecting the normal flow of people. Various provinces in China have formulated corresponding measures to control the movement of people according to the development of the epidemic situation in their localities. Among the provinces with more than 500 cumulative confirmed cases and Hubei, Guangdong's worst-affected province (which accounted for 28). $8 \%$ of China's exports in 2019), Zhejiang (13. 6\% and Jiangsu (16. $1 \%$ are major foreign trade provinces and Sichuan, Anhui, Henan, and other labor-exporting provinces [7]. The combination of these two factors will make it more difficult for Chinese export enterprises to resume work. The recovery of enterprises' production capacity depends not only on the situation of local epidemic control but also on other provinces' response measures and effects. According to the overall migration trend of the country during the Spring Festival travel rush provided by Baidu Map, compared with the situation of the 2019 Spring Festival travel rush, people returning home in the early stage of the 2020 Spring Festival travel rush were not significantly affected by the epidemic. Still, in the late stage of the Spring Festival travel rush, the epidemic had a great impact on people returning home [8].

Health International Emergency (PHEIC) by the World Health Organization (WHO) on January 31, 2020, some Contracting countries still implemented temporary controls on China's export of certain categories of commodities, although WHO did not recommend the adoption of travel or trade restrictions [9]. Most of the restricted product categories are agricultural products, which have a limited impact on China's overall exports in the short term. However, as the outbreak continues, the number of countries subject to trade restrictions will likely increase, as is the scope and intensity of temporary measures.

\subsection{Influence}

First, production and supply did not reach production. On the one hand, China is still unable to fully resume work and production. Although the resumption rate of enterprises above designated size in major industrial provinces except Hubei province has exceeded $90 \%$, the resumption rate of small and medium-sized enterprises, which account for more than $90 \%$ of the total number of enterprises in China, remains low. In normal times, they contribute $80 \%$ of China's employment, $70 \%$ of technological innovation, $60 \%$ of GDP and $50 \%$ of tax revenue [9]. They are also important supporting suppliers and service providers for large enterprises. Therefore, if China's small and medium-sized enterprises cannot fully resume work as soon as possible, it will surely drag down the export capacity of the "factory of the world". On the other hand, the epidemic has led to Italy, South Korea and the abroad enterprise shutdown crisis. If further outbreaks of Europe and the United States, Japan and South Korea upgrade and massive downtime, Chinese enterprises may also be induced with spare parts, raw materials, machinery and equipment, and supporting services for the crisis, thus intensifying the impact on China's exports.

Second, the scale of demand has declined. At present, Europe, the Us, Japan and the ROK account for about $45 \%$ of China's export market [8]. Suppose the epidemic continues to escalate in these major export markets and lead to a slowdown or recession in their economic growth. In that case, Chinese exporters may be hit hard again under the shadow of "China-Us trade frictions", and their foreign trade orders will further shrink significantly. Data from the Ministry of Commerce show that China's net export contributes about $20 \%$ to ITS GDP growth, and about 180 million people are employed by foreign trade [10]. It can be foreseen that if China's foreign trade department, due to the contraction of foreign demand and bankruptcy and layoffs, this will inevitably lead to further contraction of domestic consumer market demand, so that enterprises into a more severe sales dilemma.

Third, the industrial value chain is blocked. From the perspective of global value chain network relations, East Asia, North America and The European Union are the three core nodes of the manufacturing global value chain network. The more complex and high-tech manufacturing products are, the more inseparable they are from the collaboration of the three nodes. Based on the analysis of trade data before and after the SARS outbreak in 2003, some studies believe that the impact of COVID-19 on global trade in goods will be shortterm, partial and controllable. However, this view 
ignores the fact that the current global value chain network is much more complex than that in 2003 and may be overly optimistic. In recent years, along with the advance of logistics technology and the production pattern of the train more and more popular, more and more companies are adopting the operation mode of the zero stock or less to reduce the cost. Still, when the outbreak causes a key node of global value chain production or foreign traffic to be blocked, it will immediately disrupt the value chain of other enterprises facing a shortage of inputs into crisis, Triggering a series of global lockdowns. Therefore, even if China is in the final phase of the pandemic at home, Chinese companies are unlikely to be immune from the collapse of the GLOBAL value chain network if large parts of other major economies are shut down due to the outbreak.

\section{RESULT AND DISCUSSION}

According to the information in the paper, it shows that the Covid-19 affects China's exports and imports in different regions and different kinds of products. In a specific time period like Spring festival when a large number of people would return to home by using many kinds of public transportation. The pandemic largely reduced their chances and their way back home. The isolation makes people hard to work, and the production of daily items decrease. It was hard to increase the exchange of goods with other countries. It, in turn, reduces the net exports and affects the exchange rate. To recover the economy in China's exchange market production and price, it is important to guide foreign trade enterprises to transform, develop, and expand the production and supply of anti-epidemic materials. The paper will actively guide foreign trade enterprises to adjust their production capacity structure to meet the special global consumption needs during the epidemic prevention period and become the "world factory" supporting global epidemic prevention. On the one hand, China is the world's core production base for antiepidemic materials such as masks, protective clothing, disinfection products, basic medical equipment and drugs. [10] Under the intense mobilization of nearly two months, many well-known Chinese enterprises have crossed borders to join the production team of epidemic prevention materials, demonstrating China's unparalleled ability to deploy materials and mobilize production under the state of emergency. Although at present our country has gradually eased domestic outbreak, the paper should still continue to guide our government domestic production strength and the transformation ability of enterprises to join epidemic prevention materials production teams and helps to epidemic prevention materials production enterprises and foreign epidemic areas established counterpart underwriting the cooperation relations, production and sales of the help enterprises to expand export business at the same time. It has also contributed "Chinese strength" to the global epidemic prevention cause. On the other hand, with the spread of the global epidemic of panic, even the necessities and epidemic prevention is not directly related to the people in parts of South Korea, the European Union and the United States also have been buying up goods, various local commerce authorities and civil chamber of commerce in China can take this opportunity to help powerful local enterprises to establish trade relations with overseas well-known wholesale and retail enterprise, Actively solicit overseas orders. On the one hand, the paper will continue to promote the coordinated resumption of work and production between upstream and downstream industries. Guide local competent commercial departments to provide precise assistance, start from guaranteeing leading enterprises, promote the coordinated resumption of work and production among key enterprises, leading enterprises and supporting enterprises, and improve the systematicness and synergy of industrial chain resumption of work and production. Against the current, on the other hand, some of the industry's expose the weak links of the supply chain, our government should integrate more scientific research resources and strength, support industry of upstream and downstream enterprises to strengthen coordination and technical cooperation, strengthen industrial chain toughness, enhance the level of the industrial chain, formed in open cooperation innovation ability stronger, higher value-added industrial chain. At the same time, the paper will increase fiscal and financial support, fully implement export tax rebates, export credit insurance, and export credit support policies, and effectively reduce enterprises' costs. In addition, it is necessary to improve the foreign trade industry chain and supply chain. The paper will promote a national base for transforming and upgrading foreign trade and fully restoring production capacity in the upstream and downstream of the industrial chain with key industries and leading enterprises. The paper will promote the development of trade platforms and international marketing service systems and promote the smooth flow of supply chains at home and abroad.

\section{CONCLUSION}

This article began to analyze after the novel coronavirus epidemic in China has gradually stabilized. Before this, the epidemic in China was at a relatively serious stage in January 2020. To protect the health of citizens, the government implemented the quarantine policy, which reduced the output of all industries. But by May, the outbreak had become relatively stable across the country, and most companies and factories had resumed their previous operations and procedures. The economy has improved during this period, enabling China to export some needs to other countries experiencing the epidemic's impact. This article reviews 
the epidemic's impact in different regions at different times during the epidemic period and compares the changes before and after the epidemic. These studies found that the epidemic's impact on imports and exports was great at the beginning of the epidemic because it was difficult to ensure a stable level of domestic output value in the region. But the economy quickly recovered in the middle of the year, and export output picked up. According to historical data, China's import scale and export scale have the objective phenomenon of the same direction of change. The phenomenon is determined by China's economic and foreign trade structure. Even during the spread of SARS in 2003, the outbreak of the financial crisis in 2009 and even the continuous trade friction between China and the United States in recent years, the changing direction of China's import scale was basically the same as that of its export scale. Although the outbreak has increased the import of some medical supplies, its contribution to import growth is limited due to the limited amount of imports.

\section{REFERENCES}

[1] Meephokee, Chanin, et al. "Factors affecting trade and investment relations between Thailand and the LAO People's Democratic Republic." Thai Journal of East Asian Studies 16.1 (2011): 25-38.

[2] https:// spiral.imperial.ac.uk/ bitstream/ 10044/ 1/ 80360/ 13/ 03- 07- 2020- COVID19- Report- 30. Pdf $>$ [Accessed 25 August 2021].
[3] Peijia Li, Yiju Li. "The impact of COVID-19 on China's import and export and the response of commercial banks" Bank of China Research Institute 267 (2021.2.17)

[4] Shao Yu, Li Zhisai, Which export sectors in China have been most affected by COVID-19? Finance Magazine https:// author. baidu.com; 2021/09/11

[5] Yabing $\mathrm{Hu}$, "Risk management of ENTERPRISES' RMB exchange rate under the impact of COVID19" China Finance 11. (2020)

[6] Yang, Weiyi, Yanru Liu, and Yifei Xin. "Analysis of Influencing Factors of Import and Export Based on Neural Network Gray Prediction." a a 1 (2021): 1 .

[7] Fu, Han, et al. "Report 30: The COVID-19 epidemic trends and control measures in mainland China." (2020).

[8] Ari Chernoff, Zoey Ye Zhang, 2021 ImportExport Taxes and Duties in China, China Briefing. 2021,07.

[9] Voxeu.org. 2021. The triple effect of COVID-19 on Chinese exports | VOX, CEPR Policy Portal.

[10] Xiaolei Zhang, Weifu Zhang, Lu Cai,Qifei Chen, 2020 "Strategies for China's foreign trade development in the context of the global "pandemic" Theory Guangming Report (2020.3). 